\title{
Brain Activation in Chronic Nonspecific Low Back Pain : A Systematic review and ALE Meta-analysis
}

Sandipan Hazra', Samantak Sahu², Prasun Priya Nayak², Koushik Sarkar, Srikumar V^s, Gita Handa $^{5}$

1 Department of Physical Medicine and Rehabilitation, R. G. Kar Medical College, Kolkata, India

2 Department of Physical Medicine and Rehabilitation, All India Institute of Medical Sciences, Jodhpur, India

3 Department of Physiology, All India Institute of Medical Sciences, Jodhpur, India

4 Department of Electronics and Communication Engineering, Narula Institute of

Technology, Kolkata, India

5 Department of Physical Medicine and Rehabilitation, All India Institute of Medical

Sciences, New Delhi, India

\section{Abstract:}

Pain, a protective mechanism turns into a pathologic response when it becomes chronic. Recent evidences are pointing towards neuroplastic brain changes as the primary factor for the persisting pain in chronic nonspecific low back pain (cLBP). To summarise the previous fMRI studies, a coordinate-based ALE meta-analysis of resting functional brain imaging studies is carried out to identify the clusters activated in the brain in cLBP.

Literature survey: 'PubMed', 'Scopus' and 'Sleuth' were searched for studies with resting functional whole-brain imaging in cLBP. Till October 2020; 258, 238, and 7 studies were found respectively after search. The activity pattern was documented in 'without stimulation' and 'with stimulation' groups. The risk of bias was assessed by Joanna Briggs Institute critical appraisal checklist for analytical cross-section studies. Total seven (224 cLBP patients, 110 activation foci) and six studies (106 cLBP patients, 66 activation foci) were selected among 277 studies for metanalysis in the 'without stimulation' and 'with stimulation' group respectively. In the 'without stimulation' group 8 statistically significant clusters were found. The clusters are distributed in the prefrontal cortex, primary somatosensory cortex, and primary motor cortex, anterior cingulate cortex, insular cortex, putamen, claustrum, amygdala, and associated white matters in both hemispheres. On the other group, 3 statistically significant clusters were found in the frontal cortex, Parietal cortex, and Insula. In the 'with stimulation' group, significant lateralization was observed and most of the clusters were in the right hemisphere. The white matter involvement was more in 
medRxiv preprint doi: https://doi.org/10.1101/2021.08.26.21262683; this version posted August 28, 2021. The copyright holder for this preprint

(which was not certified by peer review) is the author/funder, who has granted medRxiv a license to display the preprint in perpetuity.

All rights reserved. No reuse allowed without permission.

Brain Activation in Chronic Nonspecific Low Back Pain : A Systematic review and ALE Meta-analysis

the 'with stimulation' group (78.62\% Vs 38.21\%). The statistically significant clusters found in this study indicate a probable imbalance in GABAergic modulation of brain circuit and dysfunction in descending pain modulation system. This disparity in pain neuro-matrix is the source of spontaneous and persisting pain in cLBP.

Keywords : Chronic nonspecific low back pain (cLBP), ALE meta-analysis, Functional magnetic resonance imaging (fMRI), Descending pain modulation system, GABAergic circuitry in brain.

\section{Main text :}

\section{Introduction:}

Pain, a cornerstone protective mechanism turns into a pathologic response when it becomes chronic. The relationship of tissue injury and nociception become dynamic and wrangled. The debate is how it becomes chronic and if it is chronic what will be the treatment strategy. From the time of French philosopher Renee Descartes (1644), pain is considered as physiologically specialized. The specific pain receptors in the body projects the information through nerve fibers in the specific regions in the brain (1). Alternatively, the recent demonstration of central sensitization is considered the pain can be maintained and modulated in brain (2). So, researchers tried to co-relate the pain in chronic non-specific low back pain (cLBP) with degenerative spinal changes and neuroplastic brain changes.

Kergel et al. (3) has pointed out neuroplastic changes in both grey and white matters in a Systematic review of functional brain imaging studies in cLBP patients. They also identified there is increased activation in few pain processing brain areas like, medial prefrontal cortex (medial PFC), cingulate cortex, amygdala and insula during rest. Increased activation was demonstrated in the medial PFC, cingulate cortex, amygdala, insula, primary somatosensory cortex (S1), primary motor cortex (M1) and secondary somatosensory cortex (S2) after painful stimuli or physical manoeuvres. In an another meta-analysis of 293 patients Yuan et al (4) has shown decrease in grey matter volume in bilateral medial prefrontal cortex (mPFC), anterior cingulate cortex and right orbitofrontal cortex. In another Systematic review of 
medRxiv preprint doi: https://doi.org/10.1101/2021.08.26.21262683; this version posted August 28, 2021. The copyright holder for this preprint

(which was not certified by peer review) is the author/funder, who has granted medRxiv a license to display the preprint in perpetuity.

All rights reserved. No reuse allowed without permission.

Brain Activation in Chronic Nonspecific Low Back Pain : A Systematic review and ALE Meta-analysis

structural and functional brain changes in chronic low back pain, authors have suggested that brain changes corroborate brain emotional network rather than nociceptive pathway (5) .

Approaches towards evaluation and treatment strategies of cLBP centred on peripheral spinal factors of cLBP has been challenged by these equivocal evidences. Recent evidences are pointing towards neuroplastic brain changes as primary factor for the persisting pain in cLBP. In the molecular and cellular level, chronic nociception leads to brain reorganization. Theses microscopic changes results in release of excitatory and inhibitory neurochemicals from neurones and glial cells, upregulation of ionotropic and metabotropic receptors by signalling pathways and alteration in presynaptic and postsynaptic neuronal excitability (6). The final outcome of these molecular changes are long-term potentiation and central sensitization (7)(8). These neuroplastic changes are reflected in altered functional brain connectivity. Therefore, there is an inevitable need to explore the mechanisms of pain in cLBP in order to optimize our diagnostic and therapeutic strategies.

In the clinical practice guideline chronic nonspecific low back pain is defined as "pain occurring primarily in the back with no signs of a serious underlying condition (such as cancer, infection, or cauda equina syndrome), spinal stenosis or radiculopathy, or another specific spinal cause (such as vertebral compression fracture or ankylosing spondylitis)” (9). Low back pain more than 3 months of duration is defined as chronic low back pain (9). Degenerative changes on imaging of lumber spine are usually considered nonspecific, as they correlate poorly with symptoms (9).

In this context the previous brain imaging studies in cLBP are summarised in this metaanalysis. The gold standard statistical analysis for imaging studies are meta-analysis from full statistical map of previously published studies by aggregating the effect size at each voxel (10). As full statistical maps are rarely available, peak co-ordinate-based methods are used commonly. This Co-ordinate based Activation likelihood estimation (ALE) analysis asses the consistency of activation in each voxel [unitary three dimensional (3D) point in 3D image, here in brain MRI]. ALE based meta-analysis of resting functional brain imaging studies is carried out to identify the areas activated in chronic nonspecific low back pain patients. 
medRxiv preprint doi: https://doi.org/10.1101/2021.08.26.21262683; this version posted August 28, 2021. The copyright holder for this preprint

(which was not certified by peer review) is the author/funder, who has granted medRxiv a license to display the preprint in perpetuity.

All rights reserved. No reuse allowed without permission.

Brain Activation in Chronic Nonspecific Low Back Pain : A Systematic review and ALE Meta-analysis

Methodology :

Registration : The protocol of this review is registered in PROSPERO (registration number : CRD42020203007).

\section{Eligibility criteria :}

Studies with resting functional whole brain imaging in patients with chronic non-specific low back pain were included. Studies without brain imaging, reviews, animal studies, case reports, without full text, non-English language studies, without any peer review, not including whole brain analysis, with only structural imaging, studies not mentioning any standard stereotactic space 3 D coordinates x,y,z ; like Talairach or Montreal Neurological Institute for peak co-ordinate were excluded. The selected studies were done in resting conditions and with or without mechanical, thermal and pressure stimulations. Previous studies have shown that in chronic low back pain patients different brain areas are activated in resting fMRI with or without thermal stimulation (11) (12). Apkarian concluded that it is difficult to interpret the functional MRI studies with mechanical and thermal stimulation in spontaneous pain like CBP (13). So, we have categorised the fMRI studies in two groups, i.e., with stimulation and without stimulation. If any eligible article has reported fMRI data in both the condition, we have included the peak co-ordinate separately.

\section{Information source : Search and Data Item:}

Literature was searched online by using 'PubMed', 'Scopus' and 'Sleuth' (BrainMap database). We have also searched the reference list of relevant studies and review articles additionally. The main keywords used were (Chronic low back pain) AND ( Brain OR Brain Activity OR Cortical changes OR Cortex OR Cortical activity OR Synapse OR Synaptic changes OR Sensorimotor processing OR Plasticity) AND (Central Nervous System Sensitization OR Sensitization OR Central sensitivity OR Central hyper-excitability OR Central sensitization OR Pain modulation OR Neural inhibition OR Hyperalgesia OR Nociception OR Pain threshold OR Algometry OR Hypersensitivity OR Gray matter OR White matter OR Functional connectivity) AND (MRI OR Magnetic resonance imaging OR fMRI OR Functional magnetic resonance imaging OR PET OR Positron emission tomography OR evoked potential OR NIRS OR fNIRS OR functional near-infrared spectroscopy OR Optical neuroimaging study OR Diffusion tensor imaging OR EEG OR Electroencephalography OR Brain imaging). Searching was done by SH \& SS independently, and was supervised by GH \& SV. All the authors has completed speciality training in 
medRxiv preprint doi: https://doi.org/10.1101/2021.08.26.21262683; this version posted August 28, 2021. The copyright holder for this preprint

(which was not certified by peer review) is the author/funder, who has granted medRxiv a license to display the preprint in perpetuity.

All rights reserved. No reuse allowed without permission.

Brain Activation in Chronic Nonspecific Low Back Pain : A Systematic review and ALE Meta-analysis

Physical Medicine and Rehabilitation. They have 6, 4, 27 and 20 years of experiences in the speciality respectively.

\section{Study Selection:}

In 'PubMed', 'Scopus' and 'Sleuth' (BrainMap online database) we have found 258, 238 and 7 studies till October 2020 respetively. Additionally, after searching the reference list of relevant studies and review articles we have found additional ten references. After removing the duplicate studies, we have found 277 studies. Out of these, 120 studies were excluded for not having brain imaging studies, reviews, animal studies, case reports, non-availability of full text, non-English language studies, studies that are not peer reviewed. From that149 studies were excluded for not having whole brain analysis, reporting structural imaging only, not mentioning standard stereotactic space coordinates (Talairach or Montreal Neurological Institute), not satisfying the case definition of chronic low back pain (9). We have divided the studies full filling the inclusion criteria in two categories, i.e, (1) without lower back stimulation and (2) with lower back stimulation. In the first group one study by Baliki et al was included in qualitative analysis only (14). Because in this study the peak co-ordinates were not reported. Finally, seven studies were included in meta-analysis in the 'without stimulation' group. In the second group six studies were included for qualitative and quantitative analysis (figure 1).

\section{Risk of bias assessment:}

Risk of bias was assessed by Joanna Briggs Institute critical appraisal check list for analytical cross-section studies, developed by Faculty of Health and Medical Sciences at the University of Adelaide, South Australia (15). It has eight items and each item have four options for answering. The answers are yes, no, unclear and not applicable.

\section{ALE Meta-analysis:}

ALE meta-analysis is summarising the co-ordinates in a voxel based analysis to know which regions are consistently activated (10). It is used to localise the pattern of anatomical brain region activated in a particular type of task. Null hypothesis for ALE method is that foci of activations are uniformly spread in the whole brain. So, this statistical method is used to assess the activation probabilities for each voxel in the brain. The null hypothesis is rejected when at least one peak co-ordinate falls within the voxels. In ALE, Monte Carlo procedure 
medRxiv preprint doi: https://doi.org/10.1101/2021.08.26.21262683; this version posted August 28, 2021. The copyright holder for this preprint

(which was not certified by peer review) is the author/funder, who has granted medRxiv a license to display the preprint in perpetuity.

All rights reserved. No reuse allowed without permission.

Brain Activation in Chronic Nonspecific Low Back Pain : A Systematic review and ALE Meta-analysis

generates n number peaks at random locations. The peaks are assumed to follow a Gaussian distribution but the mean and variance are unknown. Primarily, a random mean and standard deviation is considered. Then the mean and deviation are adjusted to minimise the objective function. Doing so, a distribution is fitted, which is closely matched with the voxel distribution and they are grouped group on similarity measures (16). ALE value is calculated by union of peak probabilities where the probability is statistically significant. Z- score is used to standardise the distribution for comparison. Resultantly, Z-score have a distribution with a mean 0 and standard deviation 1. Accordingly, this signifies how far is the point from the mean of a data point. We have used GingerALE 3.0.2 for ALE meta-analysis and this is based on the protocol proposed by Eickhoff et al. (17) (18). For the threshold of ALE map, P value for the cluster-level family-wise error (FWE) was chosen <0.05 (corrected) and for cluster formation voxel-level forming threshold $\mathrm{P}$ value was chosen $<0.001$ (uncorrected) (19)(20). The p-value can be calculated as corrected and uncorrected. The observed p-value is also known as uncorrected p-value can be adjusted as suggested by Bonferroni is known as corrected p-value. We have chosen threshold for minimum cluster size as $>200 \mathrm{~mm}^{3}$ (19). For visualization of results we have used Mango (4.1) by Research Imaging Institute, UTHSCSA and anatomical template provided on GingerALE Website (Colin27_T1_seg_MNI.nii, http://brainmap.org/ale). This template was overlaid with the ALE map generated by GingerALE 3.0.2. This ALE estimation and visualization was done by SH and KS.

\section{Results:}

Study selection: Total 8 and 6 studies was selected among 277 studies for Systematic review for the 'without stimulation' and 'with stimulation' group respectively. Relevant information from the included studies were presented in the table $1 \mathrm{a}$ and $1 \mathrm{~b}$. The following items were included (1) study, (2) objective, (3) inclusion criteria, (4) exclusion criteria, (5) participants details and (6) location of brain where peak activity is reported. Most of the studies haave mentioned, the study population were right-handed.

Risk of Bias: We have assessed the risk of bias of the 8 selected resting fMRI studies (table no 2a) and six fMRI studies with stimulation (table no $2 b$ ) in chronic non-specific low back pain by Joanna Briggs Institute critical appraisal check list.

\section{ALE meta- analysis results :}


medRxiv preprint doi: https://doi.org/10.1101/2021.08.26.21262683; this version posted August 28, 2021. The copyright holder for this preprint

(which was not certified by peer review) is the author/funder, who has granted medRxiv a license to display the preprint in perpetuity.

All rights reserved. No reuse allowed without permission.

Brain Activation in Chronic Nonspecific Low Back Pain : A Systematic review and ALE Meta-analysis

An ALE meta-analysis of total 7 and 6 selected studies was done in 'without stimulation' and 'with stimulation' group respectively. In the 'without stimulation' group, 110 activation foci was considered from a pooled data of 224 patients. In the 'with stimulation' group 66 activation was identified from a pooled data of 106 patients. Minimum cluster size was chosen as $200 \mathrm{~mm}^{3}$. Statistically significant clusters are described in the table $3 \mathrm{a} \& 3 \mathrm{~b}$, and figure $2 \mathrm{a}, 2 \mathrm{~b}$. In the 'without stimulation' group statistically significant activation found in the both hemispheres and frontal, parietal, limbic and sub-lobar regions. In the 'with stimulation' group a significant laterization was observed and most of the clusters were in right hemisphere (figure 2a,2b). Activation was observed in frontal lobe, parietal lobe, insula and limbic lobe. Both the grey and white matter areas are activated in both of groups. White matter involvement is more in fMRI studies with stimulation than without stimulation group (78.62\% Vs $38.21 \%)$.

\section{Discussion:}

The fMRI assess spatial activity in the entire brain at rest in 'with stimulation' or 'without stimulation' group in cLBP patients. In fMRI BOLD MRI signals reflect the neuronal activity based on the neuronal oxygenation. The activity pattern was different in spontaneous pain and hyperalgesia - allodynia. This is reflected in the finding of 'without stimulation' and 'with stimulation' group respectively. In this ALE meta-analysis of seven fMRI 'without stimulation' studies, we have found eight statistically significant clusters activated in 'spontaneous' chronic non-specific low back pain. Those are distributed in prefrontal-cortex, primary somatosensory cortex and primary motor cortex, anterior cingulate cortex, insular cortex, putamen, claustrum, amygdala and associated white matters (table $3 \mathrm{a}$, and figure $2 \mathrm{a}$ ). Five studies have mentioned the diagnostic criteria they have used to define cases (table 2a). Other studies included the patients diagnosed clinically among them one study did not mention the criteria. Five studies have mentioned about the confounding factors.

We have found three statistically significant clusters in ALE meta-analysis of six fMRI studies of 'with stimulation' group in chronic non-specific low back pain or in 'hyperalgesia - allodynia'. Those are in frontal cortex, parietal cortex and insula (table $3 b$, and figure $2 b$ ). In this group, five studies have mentioned the diagnostic criteria for case definition and only one study has specified about the confounding factors (table 2b). Significance of this identified clusters in cLBP is discussed in the following sections.

Pain is a multidimensional experience. According to pain matrix in the brain, four distinct 
medRxiv preprint doi: https://doi.org/10.1101/2021.08.26.21262683; this version posted August 28, 2021. The copyright holder for this preprint (which was not certified by peer review) is the author/funder, who has granted medRxiv a license to display the preprint in perpetuity. All rights reserved. No reuse allowed without permission.

Brain Activation in Chronic Nonspecific Low Back Pain : A Systematic review and ALE Meta-analysis

regions can be identified to represents the facets of pain sensation - (a) sensory motor region, (b) cognitive regions, (c) affective regions, and (d) modulatory regions [5].

\section{a) Sensory - Motor region :}

The sensory discriminative element of pain indicates the intensity i.e., when, where and how (22). Along with that, primary somatosensory cortex (S1) processes some epicritic information and secondary somatosensory cortex (S2) deals with some higher cognitive component of pain (23). Primary motor cortex involvement in the chronic pain is associated with execution of movement. In a recent meta-analysis, Chang et al. has reported inconsistent association between those (24). There are evidences of expansion and shift of cortical areas in S1, S2, M1, ACC and insular cortex with chronicity of pain (25). In the 'without stimulation' group of this study, two statistically significant clusters are found; one in right and left primary somatosensory (BA3) and the other one in primary motor cortex (BA4) (table 3a and figure 2a). Similarly, another cluster is found right S2 cortex (BA40) of the "with stimulation' group (table $3 \mathrm{~b}$ ). In this context, it is noteworthy that the insular and S1 cortex define the laterality of pain (26). The involvement of S2 cortex in the present study 'with stimulation' group possibly indicates the involvement of higher cognitive component in the case of hyperalgesia or allodynia and affective assignment of pain. Godinho et al. have concluded that a relatively late occurring responses in right somatosensory, temporooccipital and temporal hemisphere are associated with memory encoding and emotional component of pain (27). From the present analysis, one cluster was also found in supplementary motor cortex (Rt BA6) and motor association cortex (Rt BA8) in the 'with stimulation' group (table 3b, and figure $2 b$ ). Mishra et al. have shown that these areas are connected with pain and motor control (28).

\section{b) Cognitive region :}

Prefrontal activity is correlated with cognitive domain of nociception; therefore it is related with memory, attention, knowledge and understanding (23). However, Coghill et al. (29) and Strigo et al. (30) have shown that this 
medRxiv preprint doi: https://doi.org/10.1101/2021.08.26.21262683; this version posted August 28, 2021. The copyright holder for this preprint

(which was not certified by peer review) is the author/funder, who has granted medRxiv a license to display the preprint in perpetuity.

All rights reserved. No reuse allowed without permission.

Brain Activation in Chronic Nonspecific Low Back Pain : A Systematic review and ALE Meta-analysis

area is not directly related with sensation and affect. Prefrontal cortex (BA $10,9)$ is associated with modulating nociception in "top-down" approach. More precisely, orbital frontal cortex (BA10) controls the affective perception (31). Several human and animal studies have documented time dependent decrease of grey matter volume in prefrontal cortex (32). Among the selected studies for the current analysis, there are three statistically significant clusters in pre-frontal cortex, ie, left anterior prefrontal cortex (BA 10), left dorsolateral and medial prefrontal cortex (BA 9) (table 3a and figure 2a) in the 'without stimulation' group. On the contrary, we have found no significant clusters of activation in the 'with stimulation' group (table 3b). Baliki et al. have also documented increased activity in medial prefrontal cortex (mPFC) (BA12, 24, 25,32, 33) and this activity was increased by atrophy of dorsolateral prefrontal cortex $(\mathrm{BA} 8,9,10,46)(11)$. Hashmi et al. also pointed out increased activity in the mPFC amygdala and basal ganglia as a marker of cLBP (33). Further supporting these observations, the mPFC and rostral anterior cingulate cortex (rACC) have been found to have increased activity in a recent study by $\mathrm{Tu}$ et al.(34). In a Systematic review Kregel et al. also supports the involvement of pre frontal cortex in chronic low back pain (3).

\section{c) Affective region :}

Affective component denotes the 'unpleasantness' of pain perception. Activation of cortico-limbic circuitry has been postulated as a risk-factor for development of chronic pain (23). In this study, the activation is found in left and right rostral anterior cingulate cortex (rACC) (BA32, BA24), left amygdala, left anterior insula and left basal ganglia. It is evident that activation of cortico-limbic pathway is more than that of mesolimbic pathway as there are no statistically significant activation of the regions like hippocampas, thalamus and mid brain. Among the selected studies in the 'without stimulation' group, activation of left rACC [dorsal anterior cingulate cortex (ACC) (BA 32) and ventral anterior cingulate cortex (BA 24)] (table 3a and figure 2a) was documented by Baliki et al. (11), Hashmi et al (33) and 
medRxiv preprint doi: https://doi.org/10.1101/2021.08.26.21262683; this version posted August 28, 2021. The copyright holder for this preprint

(which was not certified by peer review) is the author/funder, who has granted medRxiv a license to display the preprint in perpetuity.

All rights reserved. No reuse allowed without permission.

Brain Activation in Chronic Nonspecific Low Back Pain : A Systematic review and ALE Meta-analysis

Tu et al.(34). Tolle et al (35) and Zubieta et al (36) also have shown ACC is more related with affective component of pain.

Insular cortex (IC) has been found to be involved in sensory and affective dimensions of pain. Anterior insula performs as an integration site for multimodal information of pain including attention, anticipation and belief (23). It is also associated with pain intensity and and possible pain amplification (37). It has circuitry connection with PFC, ACC, amygdala and descending pain modulation system. Initially the glutaminergic receptors plays role in chronification of pain in IC. Subsequently, the imbalance between the glutaminergic, GABAergic and dopaminergic pathways contributing to the dysfunction in the pain processing and modulation (38). In both "with stimulation' and 'without stimulation' groups, one cluster is found in insular cortex (BA13) in right and left lobe respectively (table 3a \& 3b and figure 2a $\& 2 b)$. Contralateral involvement of insula in the with stimulation group may be due to laterality of nociception as described in the previous section.

In the pain processing, circuitries of central amygdala $(\mathrm{CaA})$ and basolateral amygdala (BLA) complex act in conjunction. The $\mathrm{CaA}$ is associated with negative emotional aspects of pain and named as 'nociceptive amygdala'(39). Whereas, BLA integrates polymodal sensory information (both noxious and non-noxious) and generate a memory regarding nociception (23). Amygdala acts as a central component of GABAergic circuitry in brain and controls the reward-aversion circuitry. It receives sensory information from spinal lamina 1 through spino-reticular pathway (parabrachial neucleus). Amygdala sends information to PFC and ACC and control the descending pain modulating system by periaqueductal grey (PAG) and rostral ventrolateral medulla (RVM) (23). In this meta-analysis, one statistically significant cluster is found in this area in 'without stimulation' group (table 3a, figure 2a).

In the present analysis, two clusters are noted in the basal ganglia (Cluster 6, putamen and Cluster 4 claustrum) (table 3a, figure 2a). Basal ganglia is associated with motor, associative and emotional processing of pain (40). Putamen, in particular, is concerned in maintaining somatotopic map of pain (41) and subjective rating of pain (42). 
medRxiv preprint doi: https://doi.org/10.1101/2021.08.26.21262683; this version posted August 28, 2021. The copyright holder for this preprint (which was not certified by peer review) is the author/funder, who has granted medRxiv a license to display the preprint in perpetuity. All rights reserved. No reuse allowed without permission.

Brain Activation in Chronic Nonspecific Low Back Pain : A Systematic review and ALE Meta-analysis

\section{d) Modulatory region :}

Electrical stimulation to peri-aqueductal grey (PAG) produces anti-nociceptive effect in dorsal horn spinal cord circuitry. The PAG output pathway is under influences of PFC and $\mathrm{ACC}$ and this connection is predominantly GABaergic. In cLBP patients this descending circuitry to PAG displays abnormal functional connectivity (43). The PAG-Spinal cord projection routes through rostral ventrolateral medulla (RMV). The PFC also acts as a connecting node in BLA-PFC-PAG circuitry. Prefrontal deactivation depresses this antinociceptive descending pathway. The final outcome is increased descending facilitation and decreased inhibition (pro-nociceptive) of PAGRMV-spinal cord circuit (23). This pro-nociceptive priming of RMV causes reduction of threshold of activation of both ON and OFF cells to innocuous stimuli in chronic pain. The failure of compensatory rebalance and decreased top down modulation make the circuitry nocifensive (44). In this present study no significant cluster is identified in the descending pain modulatory region in either of the study groups (table $3 \mathrm{a} \& 3 \mathrm{~b}$ ). This is probably due to decrease in PFC-PAG output.

The white matter involvement is greater in the 'with stimulation' group than the other one (78.62\% Vs 38.21\%) (table 3a and 3b). The chronic pain is associated with both 'neuropathy' and 'gliopathy'. After injury, glial modulators causes activation of microglia and astrocytes. The activated glial cells release various neuromodulators and ultimately these induces synaptic and neuronal plasticity (45) (46). Perhaps the increase in white matter involvement in 'with stimulation' group is because of central sensitivity.

In this study, a stringent case definition of cLBP was followed to exclude the heterogenicity and ambiguity of case definition. This excludes few experiments included in the previous Systematic reviews. This face-off between power and homogeneity reduces the power of this study and this may affect the generalisability of the result (20). The data from the fMRI studies was extracted manually and was double checked by SH and KS to minimise the chances of error. The selected studies were of cross sectional study design with mode. Few studies didn't mention about the diagnostic criteria and the confounding factors. Future metaanalysis with combining all the spatio-temporal domain of fMRI studies could be interesting. Additionally, inclusion of more with specific case definition in cLBP can increase the meta- 
medRxiv preprint doi: https://doi.org/10.1101/2021.08.26.21262683; this version posted August 28, 2021. The copyright holder for this preprint

(which was not certified by peer review) is the author/funder, who has granted medRxiv a license to display the preprint in perpetuity.

All rights reserved. No reuse allowed without permission.

Brain Activation in Chronic Nonspecific Low Back Pain : A Systematic review and ALE Meta-analysis

analysis.

The nodes for the circuits are S1 cortex, rostral ACC (BA 32,24), prelimbic PFC (BA 10,9) and amygdala. Basal ganglia (putamen and claustrum) and M1 cortex activation are also noted along with these areas. These areas are involved in the cognitive, affective and sensory discriminative- efferent responses to pain. Nevertheless, no statistically significant activation is found in infra-limbic area (BA25), periaqueductal, rostral ventral medullary area and parabrachial area. These areas are associated with descending pain modulation system. There is no significant cluster found in the descending pain modulatory region in this meta-analysis. Hence, the fine-tuning balance between descending facilitation and inhibition in this circuit is altered. The resultant dysfunction in recruitment of descending pain modulation system create the circuit pro-nociceptive.

This meta-analysis of resting fMRI studies identified the statistically significant activation clusters in spontaneous pain and hyperalgesia - allodynia in cLBP patients. No activation is found in PAG-RMV-Spinal cord axis. Possibly the imbalance in GABAergic circuitry leads to dysfunction of descending pain modulation system and this altered pain neuro-matrix is the key mechanism for the persisting pain in cLBP.

\section{References :}

1. Melzack R, Wall PD. Pain mechanisms: a new theory. Science. 1965 Nov 19;150(3699):971-9.

2. Perl ER. Ideas about pain, a historical view. Nat Rev Neurosci. 2007 Jan;8(1):71-80.

3. Kregel J, Meeus M, Malfliet A, Dolphens M, Danneels L, Nijs J, et al. Structural and functional brain abnormalities in chronic low back pain: A systematic review. Semin Arthritis Rheum. 2015 Oct;45(2):229-37.

4. Yuan C, Shi H, Pan P, Dai Z, Zhong J, Ma H, et al. Gray Matter Abnormalities Associated With Chronic Back Pain: A Meta-Analysis of Voxel-based Morphometric Studies. Clin J Pain. 2017 Nov;33(11):983-90.

5. Ng SK, Urquhart DM, Fitzgerald PB, Cicuttini FM, Hussain SM, Fitzgibbon BM. The Relationship Between Structural and Functional Brain Changes and Altered Emotion and Cognition in Chronic Low Back Pain Brain Changes: A Systematic Review of MRI and fMRI Studies. Clin J Pain. 2018 Mar;34(3):237-61.

6. Greenwald JD, Shafritz KM. An Integrative Neuroscience Framework for the Treatment of Chronic Pain: From Cellular Alterations to Behavior. Front Integr Neurosci. 2018;12:18. 
medRxiv preprint doi: https://doi.org/10.1101/2021.08.26.21262683; this version posted August 28, 2021. The copyright holder for this preprint (which was not certified by peer review) is the author/funder, who has granted medRxiv a license to display the preprint in perpetuity. All rights reserved. No reuse allowed without permission.

Brain Activation in Chronic Nonspecific Low Back Pain : A Systematic review and ALE Meta-analysis

7. Ji R-R, Kohno T, Moore KA, Woolf CJ. Central sensitization and LTP: do pain and memory share similar mechanisms? Trends Neurosci. 2003 Dec;26(12):696-705.

8. Latremoliere A, Woolf CJ. Central sensitization: a generator of pain hypersensitivity by central neural plasticity. J Pain. 2009 Sep;10(9):895-926.

9. Chou R, Qaseem A, Snow V, Casey D, Cross JT, Shekelle P, et al. Diagnosis and treatment of low back pain: a joint clinical practice guideline from the American College of Physicians and the American Pain Society. Ann Intern Med. 2007 Oct 2;147(7):478-91.

10. Kober H, Wager TD. Meta-analysis of neuroimaging data. Wiley Interdiscip Rev Cogn Sci. 2010 Mar;1(2):293-300.

11. Baliki MN, Chialvo DR, Geha PY, Levy RM, Harden RN, Parrish TB, et al. Chronic Pain and the Emotional Brain: Specific Brain Activity Associated with Spontaneous Fluctuations of Intensity of Chronic Back Pain. J Neurosci. 2006 Nov 22;26(47):1216573.

12. Foss JM, Apkarian AV, Chialvo DR. Dynamics of pain: fractal dimension of temporal variability of spontaneous pain differentiates between pain States. J Neurophysiol. 2006 Feb;95(2):730-6.

13. Apkarian AV. Pain and Brain Changes. In: Practical Management of Pain [Internet]. 5th ed. Philadelphia, PA: Elsevier/Mosby; 2014. p. 113-131.e4. Available from: https://www.clinicalkey.com/\#!/content/book/3-s2.0B9780323083409000104?scrollTo=\%23hl0000481

14. Baliki MN, Mansour AR, Baria AT, Apkarian AV. Functional Reorganization of the Default Mode Network across Chronic Pain Conditions. PLoS One [Internet]. 2014 Sep 2;9(9). Available from: https://www.ncbi.nlm.nih.gov/pmc/articles/PMC4152156/

15. Moola S, Munn Z, Tufanaru C, Aromataris E, Sears K, Sfetc R, et al. Chapter 7: Systematic Reviews of Etiology and Risk. In: Aromataris E, Munn Z, editors. JBI Manual for Evidence Synthesis [Internet]. JBI; 2020. Available from:

https://wiki.jbi.global/display/MANUAL/Chapter+7\%3A+Systematic+reviews+of+etiol ogy+and+risk

16. Wager TD, Lindquist M, Kaplan L. Meta-analysis of functional neuroimaging data: current and future directions. Soc Cogn Affect Neurosci. 2007 Jun;2(2):150-8.

17. Eickhoff SB, Laird AR, Grefkes C, Wang LE, Zilles K, Fox PT. Coordinate-based activation likelihood estimation meta-analysis of neuroimaging data: a random-effects approach based on empirical estimates of spatial uncertainty. Hum Brain Mapp. 2009 Sep;30(9):2907-26.

18. Eickhoff SB, Bzdok D, Laird AR, Kurth F, Fox PT. Activation Likelihood Estimation meta-analysis revisited. Neuroimage. 2012 Feb 1;59(3):2349-61.

19. Eickhoff SB, Nichols TE, Laird AR, Hoffstaedter F, Amunts K, Fox PT, et al. Behavior, sensitivity, and power of activation likelihood estimation characterized by massive empirical simulation. Neuroimage. 2016 Aug 15;137:70-85. 
medRxiv preprint doi: https://doi.org/10.1101/2021.08.26.21262683; this version posted August 28, 2021. The copyright holder for this preprint

(which was not certified by peer review) is the author/funder, who has granted medRxiv a license to display the preprint in perpetuity. All rights reserved. No reuse allowed without permission.

Brain Activation in Chronic Nonspecific Low Back Pain : A Systematic review and ALE Meta-analysis

20. Müller VI, Cieslik EC, Laird AR, Fox PT, Radua J, Mataix-Cols D, et al. Ten simple rules for neuroimaging meta-analysis. Neurosci Biobehav Rev. 2018 Jan;84:151-61.

21. Borsook D, Sava S, Becerra L. The pain imaging revolution: advancing pain into the 21st century. Neuroscientist. 2010 Apr;16(2):171-85.

22. Talbot K, Madden VJ, Jones SL, Moseley GL. The sensory and affective components of pain: are they differentially modifiable dimensions or inseparable aspects of a unitary experience? A systematic review. Br J Anaesth. 2019 Aug;123(2):e263-72.

23. Kuner R, Kuner T. Cellular Circuits in the Brain and Their Modulation in Acute and Chronic Pain. Physiol Rev. 2021 Jan 1;101(1):213-58.

24. Chang W-J, O'Connell NE, Beckenkamp PR, Alhassani G, Liston MB, Schabrun SM. Altered Primary Motor Cortex Structure, Organization, and Function in Chronic Pain: A Systematic Review and Meta-Analysis. J Pain. 2018 Apr;19(4):341-59.

25. Kuner R, Flor H. Structural plasticity and reorganisation in chronic pain. Nat Rev Neurosci. 2016 Dec 15;18(1):20-30.

26. Apkarian AV, Bushnell MC, Schweinhardt P. Representation of Pain in the Brain. In: Wall \& Melzack's Textbook of Pain. 6th ed. Elsevier Health Sciences; 2013. p. 111-28.

27. Godinho F, Magnin M, Frot M, Perchet C, Garcia-Larrea L. Emotional modulation of pain: is it the sensation or what we recall? J Neurosci. 2006 Nov 1;26(44):11454-61.

28. Misra G, Coombes SA. Neuroimaging Evidence of Motor Control and Pain Processing in the Human Midcingulate Cortex. Cereb Cortex. 2015 Jul;25(7):1906-19.

29. Coghill RC, Sang CN, Maisog JM, Iadarola MJ. Pain intensity processing within the human brain: a bilateral, distributed mechanism. J Neurophysiol. 1999 Oct;82(4):193443.

30. Strigo IA, Duncan GH, Boivin M, Bushnell MC. Differentiation of visceral and cutaneous pain in the human brain. J Neurophysiol. 2003 Jun;89(6):3294-303.

31. Lorenz J, Cross DJ, Minoshima S, Morrow TJ, Paulson PE, Casey KL. A unique representation of heat allodynia in the human brain. Neuron. 2002 Jul 18;35(2):383-93.

32. Apkarian AV, Sosa Y, Sonty S, Levy RM, Harden RN, Parrish TB, et al. Chronic back pain is associated with decreased prefrontal and thalamic gray matter density. $\mathbf{J}$ Neurosci. 2004 Nov 17;24(46):10410-5.

33. Hashmi JA, Baliki MN, Huang L, Baria AT, Torbey S, Hermann KM, et al. Shape shifting pain: chronification of back pain shifts brain representation from nociceptive to emotional circuits. Brain. 2013 Sep;136(9):2751-68.

34. Tu Y, Jung M, Gollub RL, Napadow V, Gerber J, Ortiz A, et al. Abnormal medial prefrontal cortex functional connectivity and its association with clinical symptoms in chronic low back pain. Pain. 2019 Jun;160(6):1308-18. 
medRxiv preprint doi: https://doi.org/10.1101/2021.08.26.21262683; this version posted August 28, 2021. The copyright holder for this preprint (which was not certified by peer review) is the author/funder, who has granted medRxiv a license to display the preprint in perpetuity. All rights reserved. No reuse allowed without permission.

Brain Activation in Chronic Nonspecific Low Back Pain : A Systematic review and ALE Meta-analysis

35. Tölle TR, Kaufmann T, Siessmeier T, Lautenbacher S, Berthele A, Munz F, et al. Region-specific encoding of sensory and affective components of pain in the human brain: a positron emission tomography correlation analysis. Ann Neurol. 1999 Jan;45(1):40-7.

36. Zubieta JK, Smith YR, Bueller JA, Xu Y, Kilbourn MR, Jewett DM, et al. Regional mu opioid receptor regulation of sensory and affective dimensions of pain. Science. 2001 Jul 13;293(5528):311-5.

37. Tracey I, Mantyh PW. The cerebral signature for pain perception and its modulation. Neuron. 2007 Aug 2;55(3):377-91.

38. Lu C, Yang T, Zhao H, Zhang M, Meng F, Fu H, et al. Insular Cortex is Critical for the Perception, Modulation, and Chronification of Pain. Neurosci Bull. 2016 Feb 22;32(2):191-201.

39. Neugebauer V. Amygdala pain mechanisms. Handb Exp Pharmacol. 2015;227:261-84.

40. Borsook D, Upadhyay J, Chudler EH, Becerra L. A key role of the basal ganglia in pain and analgesia - insights gained through human functional imaging. Mol Pain. 2010 May $13 ; 6: 27$.

41. Bingel U, Gläscher J, Weiller C, Büchel C. Somatotopic representation of nociceptive information in the putamen: an event-related fMRI study. Cereb Cortex. 2004 Dec;14(12):1340-5.

42. Scott DJ, Heitzeg MM, Koeppe RA, Stohler CS, Zubieta J-K. Variations in the Human Pain Stress Experience Mediated by Ventral and Dorsal Basal Ganglia Dopamine Activity. J Neurosci. 2006 Oct 18;26(42):10789-95.

43. Yu R, Gollub RL, Spaeth R, Napadow V, Wasan A, Kong J. Disrupted functional connectivity of the periaqueductal gray in chronic low back pain. Neuroimage Clin. 2014;6:100-8.

44. Heinricher MM. Pain Modulation and the Transition from Acute to Chronic Pain. Adv Exp Med Biol. 2016;904:105-15.

45. Ji R-R, Berta T, Nedergaard M. Glia and pain: Is chronic pain a gliopathy? Pain. 2013 Dec;154(0 1):S10-28.

46. Ji R-R, Chamessian A, Zhang Y-Q. Pain regulation by non-neuronal cells and inflammation. Science. 2016 Nov 4;354(6312):572-7.

47. Tagliazucchi E, Balenzuela P, Fraiman D, Chialvo DR. Brain resting state is disrupted in chronic back pain patients. Neurosci Lett. 2010 Nov 12;485(1):26-31.

48. Tagliazucchi E, Balenzuela P, Fraiman D, Montoya P, Chialvo DR. Spontaneous BOLD event triggered averages for estimating functional connectivity at resting state. Neurosci Lett. 2011 Jan 20;488(2):158-63. 
medRxiv preprint doi: https://doi.org/10.1101/2021.08.26.21262683; this version posted August 28, 2021. The copyright holder for this preprint (which was not certified by peer review) is the author/funder, who has granted medRxiv a license to display the preprint in perpetuity. All rights reserved. No reuse allowed without permission.

Brain Activation in Chronic Nonspecific Low Back Pain : A Systematic review and ALE Meta-analysis

49. Baliki MN, Petre B, Torbey S, Herrmann KM, Huang L, Schnitzer TJ, et al. Corticostriatal functional connectivity predicts transition to chronic back pain. Nat Neurosci. 2012 Jul 1;15(8):1117-9.

50. Pain IA for the $S$ of, Taxonomy IA for the $S$ of PTF on. Classification of Chronic Pain: Descriptions of Chronic Pain Syndromes and Definitions of Pain Terms. IASP Press; 1994. $244 \mathrm{p}$.

51. Kong J, Spaeth RB, Wey H-Y, Cheetham A, Cook AH, Jensen K, et al. S1 is associated with chronic low back pain: a functional and structural MRI study. Mol Pain. 2013 Aug 21;9:43.

52. Werneke MW, Hart DL. Categorizing patients with occupational low back pain by use of the Quebec Task Force Classification system versus pain pattern classification procedures: discriminant and predictive validity. Phys Ther. 2004 Mar;84(3):243-54.

53. Derbyshire SWG, Jones AKP, Creed F, Starz T, Meltzer CC, Townsend DW, et al. Cerebral responses to noxious thermal stimulation in chronic low back pain patients and normal controls. Neuroimage. 2002 May;16(1):158-68.

54. Giesecke T, Gracely RH, Grant MAB, Nachemson A, Petzke F, Williams DA, et al. Evidence of augmented central pain processing in idiopathic chronic low back pain. Arthritis Rheum. 2004 Feb;50(2):613-23.

55. Deyo RA, Weinstein JN. Low back pain. N Engl J Med. 2001 Feb 1;344(5):363-70.

56. Lloyd D, Findlay G, Roberts N, Nurmikko T. Differences in low back pain behavior are reflected in the cerebral response to tactile stimulation of the lower back. Spine (Phila Pa 1976). 2008 May 20;33(12):1372-7.

57. Kobayashi Y, Kurata J, Sekiguchi M, Kokubun M, Akaishizawa T, Chiba Y, et al. Augmented cerebral activation by lumbar mechanical stimulus in chronic low back pain patients: an FMRI study. Spine (Phila Pa 1976). 2009 Oct 15;34(22):2431-6.

58. Matsuo Y, Kurata J, Sekiguchi M, Yoshida K, Nikaido T, Konno S-I. Attenuation of cortical activity triggering descending pain inhibition in chronic low back pain patients: a functional magnetic resonance imaging study. J Anesth. 2017 Aug;31(4):523-30.

\section{Tables :}

Table 1a : Summary of included fMRI studies in 'without stimulation' group 
medRxiv preprint doi: https://doi.org/10.1101/2021.08.26.21262683; this version posted August 28, 2021. The copyright holder for this preprint (which was not certified by peer review) is the author/funder, who has granted medRxiv a license to display the preprint in perpetuity.

All rights reserved. No reuse allowed without permission.

Brain Activation in Chronic Nonspecific Low Back Pain : A Systematic review and ALE Meta-analysis

\begin{tabular}{|c|c|c|c|c|c|}
\hline $\begin{array}{l}\text { Study and } \\
\text { imaging } \\
\text { method used }\end{array}$ & Objective & $\begin{array}{l}\text { Inclusion } \\
\text { criteria }\end{array}$ & $\begin{array}{l}\text { Exclusion } \\
\text { criteria }\end{array}$ & Participants & $\begin{array}{l}\text { Peak activity reported in } \\
\text { imaging }\end{array}$ \\
\hline $\begin{array}{l}\text { Baliki MN } \\
\text { et al.(11), } \\
\text { fMRI }\end{array}$ & $\begin{array}{l}\text { Effect of brain } \\
\text { morphological } \\
\text { changes in chronic } \\
\text { spontaneous low } \\
\text { back pain }\end{array}$ & $\begin{array}{l}\text { Clinically } \\
\text { diagnosed, } \\
\text { Beck's } \\
\text { Depression } \\
\text { Inventory, } \\
\text { Beck's anxity } \\
\text { index }\end{array}$ & $\begin{array}{l}\text { Not } \\
\text { mentioned }\end{array}$ & $\begin{array}{l}24 \mathrm{cLBP}(18 \mathrm{~F}, 6 \mathrm{M} \text {, } \\
\text { Gr1 } 49.2 \pm 17.2 \text { and } \\
\text { Gr2 } 50 \pm 12) \\
11 \mathrm{HC}(6 \mathrm{~F}, 5 \mathrm{M}, 48.7 \pm \\
11.2)\end{array}$ & $\begin{array}{l}\text { Insular activity reflects } \\
\text { chronicity and mPFC } \\
\text { activity reflects intensity } \\
\text { of cLBP and enhanced by } \\
\text { atrophy in DLPFC }\end{array}$ \\
\hline $\begin{array}{l}\text { Tagliazucchi } \\
\text { et al. (47), } \\
\text { fMRI }\end{array}$ & $\begin{array}{l}\text { Alteration of brain } \\
\text { default mode } \\
\text { network (DMN) } \\
\text { in cLBP }\end{array}$ & $\begin{array}{l}\text { Clinically } \\
\text { diagnosed, } \\
\text { Beck's } \\
\text { Depression } \\
\text { Inventory, } \\
\text { Beck's anxity } \\
\text { index }\end{array}$ & $\begin{array}{l}\text { Not } \\
\text { mentioned }\end{array}$ & $\begin{array}{l}12 \operatorname{cLBP}(51.2) \\
20 \mathrm{HC}(38.4)\end{array}$ & $\begin{array}{l}\text { orbital part of the middle } \\
\text { frontal gyrus, right and left } \\
\text { angular gyri, Rt } \\
\text { Precuneus, Rt inferior } \\
\text { parital cortex, Rt and Lt } \\
\text { Insula }\end{array}$ \\
\hline $\begin{array}{l}\text { Tagliazucchi } \\
\text { et al. (48), } \\
\text { fMRI }\end{array}$ & $\begin{array}{l}\text { Demonstrate the } \\
\text { methods to estimate } \\
\text { functional } \\
\text { connectivity at } \\
\text { resting state by } \\
\text { resting BOLD } \\
\text { event triggered } \\
\text { averages in cLBP }\end{array}$ & $\begin{array}{l}\text { Clinically } \\
\text { diagnosed, } \\
\text { Beck's } \\
\text { Depression } \\
\text { Inventory, } \\
\text { Beck's anxity } \\
\text { index }\end{array}$ & $\begin{array}{l}\text { Not } \\
\text { mentioned }\end{array}$ & $\begin{array}{l}13 \operatorname{cLBP}(51.2) \\
12 \mathrm{HC}(38.4)\end{array}$ & $\begin{array}{l}\text { Precentral gyrus, } \\
\text { Supplementary motor } \\
\text { area, Cerebellum }\end{array}$ \\
\hline $\begin{array}{l}\text { Baliki } \\
\text { et al. (49), } \\
\text { fMRI }\end{array}$ & $\begin{array}{l}\text { Longitudinal study } \\
\text { to identify changes } \\
\text { in brain structure } \\
\text { and function that } \\
\text { correlate with } \\
\text { persistent Low } \\
\text { back pain }\end{array}$ & $\begin{array}{l}\text { Not } \\
\text { mentioned }\end{array}$ & $\begin{array}{l}\text { Not } \\
\text { mentioned }\end{array}$ & $\begin{array}{l}39 \text { cLBP }(40.9 \pm 2.3) \\
(20 \mathrm{~F}, 19 \mathrm{M}) \\
17 \mathrm{HC}(37.7 \pm 1.8) \\
(7 \mathrm{~F}, 10 \mathrm{M}) \\
(\mathrm{Mean} \pm \mathrm{SEM})\end{array}$ & $\begin{array}{l}\text { Rt and Lt nucleus } \\
\text { accumbens, Rt putamen, } \\
\text { Rt caudate, Rt insula, Lt } \\
\text { putamen, Lt insula, Lt } \\
\text { caudate, left M1 left } \\
\text { S1 left Inferior temporal } \\
\text { gyrus, Rt middle temporal } \\
\text { gyrus }\end{array}$ \\
\hline $\begin{array}{l}\text { Hashmi et al } \\
(33), \text { fMRI }\end{array}$ & $\begin{array}{l}\text { Cross- sectional } \\
\text { and longitudinal } \\
\text { anatomical and }\end{array}$ & $\begin{array}{l}\text { IASP criteria } \\
\text { for back pain }\end{array}$ & $\begin{array}{l}\text { chronic } \\
\text { painful } \\
\text { conditions, }\end{array}$ & $\begin{array}{l}59 \text { cLBP }(25 \mathrm{~F}, 34 \mathrm{M} \\
48.8 \pm 1.2) \\
94 \mathrm{SBP}\end{array}$ & $\begin{array}{l}\text { Lt and Rt putamen, medial } \\
\text { prefrontal cortex, } \\
\text { Orbitofrontal cortex, Lt }\end{array}$ \\
\hline
\end{tabular}


medRxiv preprint doi: https://doi.org/10.1101/2021.08.26.21262683; this version posted August 28, 2021. The copyright holder for this preprint (which was not certified by peer review) is the author/funder, who has granted medRxiv a license to display the preprint in perpetuity.

All rights reserved. No reuse allowed without permission.

Brain Activation in Chronic Nonspecific Low Back Pain : A Systematic review and ALE Meta-analysis

\begin{tabular}{|c|c|c|c|c|c|}
\hline & $\begin{array}{l}\text { functional brain } \\
\text { imaging cohort } \\
\text { study fot } \\
\text { spatiotemporal } \\
\text { dynamical } \\
\text { reorganization of } \\
\text { brain activity in } \\
\text { CLBP }\end{array}$ & $\begin{array}{l}(50), \\
V A S>40 / 100, \\
c L B P>6 m \\
\text { and } S B P>16 \\
\text { weeks }\end{array}$ & $\begin{array}{l}\text { systemic } \\
\text { disease, } \\
\text { history of } \\
\text { head injury } \\
\text { or coma, } \\
\text { psychiatric } \\
\text { diseases, or } \\
\text { more than } \\
\text { mild to mod- } \\
\text { erate } \\
\text { depression } \\
\text { (Beck } \\
\text { Depression } \\
\text { Inventory } \\
\text { score }>19 \text { ) }\end{array}$ & $\begin{array}{l}(48 \mathrm{~F}, 46 \mathrm{M}, 42.1 \pm 1.15) \\
(\text { Mean } \pm \text { SEM })\end{array}$ & and Rt amygdala \\
\hline $\begin{array}{l}\text { Kong et al. } \\
\text { (51), fMRI }\end{array}$ & $\begin{array}{l}\text { Differences } \\
\text { between Brain } \\
\text { resting state } \\
\text { functional } \\
\text { connectivity } \\
\text { patients among } \\
\text { chronic low back } \\
\text { pain and control }\end{array}$ & $\begin{array}{l}\text { Quebec Low } \\
\text { Back Pain } \\
\text { Task Force } \\
\text { classification } \\
\text { criteria for } \\
\text { Classes I or II } \\
>6 \mathrm{~m}(52)\end{array}$ & $\begin{array}{l}\text { Not } \\
\text { mentioned }\end{array}$ & $\begin{array}{l}18 \text { cLBP } \\
(12 \mathrm{~F}, 6 \mathrm{M}, 36.1 \pm 9.9) \\
18 \mathrm{HC} \\
(12 \mathrm{~F}, 6 \mathrm{M}, 37.11 \\
\pm 9.24)\end{array}$ & $\begin{array}{l}\text { Rt Precentral Gyrus, left } \\
\text { fusiform gyrus, occipital } \\
\text { gyrus, right posterior } \\
\text { cingulate cortex, and } \\
\text { inferior parietal gyrus, R. } \\
\text { Precuneus, R. Uncus, S1 } \\
\text { region }\end{array}$ \\
\hline $\begin{array}{l}\text { Baliki et al. } \\
\text { (14), fMRI } \\
\text { (SR only) }\end{array}$ & $\begin{array}{l}\text { To investigate } \\
\text { functional changes } \\
\text { in patients suffering } \\
\text { from chronic back } \\
\text { pain }\end{array}$ & $\begin{array}{l}\text { IASP criteria } \\
\text { for back pain } \\
(50), \text { Beck's } \\
\text { Depression } \\
\text { Inventory } \\
(B D I) \\
(B D I<19)\end{array}$ & $\begin{array}{l}\text { Not } \\
\text { Mentioned }\end{array}$ & $\begin{array}{l}18 \mathrm{cLBP} \\
(5 \mathrm{~F}, 13 \mathrm{M}, 51.55 \\
\pm 1.87(\mathrm{Mean} \\
\pm \mathrm{SEM})) \\
18 \mathrm{HC} \\
(24 \mathrm{~F}, 12 \mathrm{M}, 41.36 \\
\pm 2.05 \\
\pm \text { SEM }))\end{array}$ & $\begin{array}{l}\text { Medial pre-frontal cortex, } \\
\text { Precuneus, } \\
\text { Rt lateral parietal region, } \\
\text { anterior cingulate cortex, } \\
\text { Lt anterior insula/inferior- } \\
\text { frontal gyrus, } \\
\text { Lt supramarginal gyrus }\end{array}$ \\
\hline $\begin{array}{l}\text { Tu et al. } \\
(34), \text { fMRI }\end{array}$ & $\begin{array}{l}\text { Resting-state fMRI } \\
\text { and multivariate } \\
\text { pattern analysis } \\
\text { were used to } \\
\text { identify abnormal } \\
\text { functional } \\
\text { connectivity in } \\
\text { chronic low back } \\
\text { pain }\end{array}$ & $\begin{array}{l}\text { Patient } \\
\text { Reported } \\
\text { Outcomes } \\
\text { Measurement } \\
\text { Information } \\
\text { System } \\
\text { (PROMIS-29) } \\
\text { Mentioned }\end{array}$ & Mentioned $^{\#}$ & $\begin{array}{l}\text { Cohort } 1 \\
50 \mathrm{cLBP}(31 \mathrm{~F}, 19 \mathrm{M} \text {, } \\
39.5 \pm 13.0 \\
44 \mathrm{HC}(19 \mathrm{~F}, 25 \mathrm{M}, \\
36.9 \pm 8.2) \\
\text { Cohort } 2 \\
30 \mathrm{cLBP}(14 \mathrm{~F}, 16 \mathrm{M}, \\
35.0 \pm 9.0) \\
30 \mathrm{HC}(16 \mathrm{~F}, 14 \mathrm{M} \text {, } \\
34.2 \pm 1.5)\end{array}$ & $\begin{array}{l}\text { Anterior cingulate cortex, } \\
\text { Precuneus mPFC, angular } \\
\text { gyrus, posterior cingulate } \\
\text { cortex, Superior frontal } \\
\text { gyrus }\end{array}$ \\
\hline
\end{tabular}


medRxiv preprint doi: https://doi.org/10.1101/2021.08.26.21262683; this version posted August 28, 2021. The copyright holder for this preprint (which was not certified by peer review) is the author/funder, who has granted medRxiv a license to display the preprint in perpetuity.

All rights reserved. No reuse allowed without permission.

Brain Activation in Chronic Nonspecific Low Back Pain : A Systematic review and ALE Meta-analysis

ACC: Anterior cingulate cortex, cLBP : Chronic non-specific low back pain, DLPFC: Dorsolateral Prefrontal cortex, F: Female, HC : Healthy control, IASP : International association for the study of pain, Lt : Left M : Male, mPFC: Medial prefrontal cortex, Rt : Right, SEM : Standard error of mean, SR : Systematic Review, Age is given in mean \pm SD if not specified otherwise. \# Supplementary material 1

Table 1b : Summary of included fMRI studies in 'with stimulation' group

\begin{tabular}{|c|c|c|c|c|c|c|}
\hline $\begin{array}{l}\text { Study and } \\
\text { imaging } \\
\text { method used }\end{array}$ & Objective & $\begin{array}{l}\text { Inclusion } \\
\text { criteria }\end{array}$ & $\begin{array}{l}\text { Exclusion } \\
\text { criteria }\end{array}$ & Participants & $\begin{array}{l}\text { Type of } \\
\text { stimulu } \\
\text { S }\end{array}$ & $\begin{array}{l}\text { Peak activity } \\
\text { reported in } \\
\text { imaging }\end{array}$ \\
\hline $\begin{array}{l}\text { Derbyshire } \\
\text { et al. (53), } \\
\text { PET-MRI } \\
\text { coregistratio } \\
\text { n }\end{array}$ & $\begin{array}{l}\text { Central } \\
\text { responses to } \\
\text { noxious } \\
\text { stimulation in } \\
\text { patients } \\
\text { suffering } \\
\text { NSLBP } \\
\text { compared } \\
\text { with a group } \\
\text { of control } \\
\text { subjects }\end{array}$ & $\begin{array}{l}\text { Clinically } \\
\text { diagnosis of } \\
\text { low back } \\
\text { pain and } \\
\text { radiologicall } \\
\text { y included } \\
\text { patients with } \\
\text { normal } \\
\text { lumbosacral } \\
\text { and brain } \\
\text { MRI }\end{array}$ & $\begin{array}{l}\text { Exclude } \\
\text { patients with } \\
\text { abnormal brain } \\
\text { MRI and } \\
\text { neuro- logical } \\
\text { deficit or } \\
\text { indication of } \\
\text { such a deficit }\end{array}$ & $\begin{array}{l}16 \mathrm{cLBP} \\
(12 \mathrm{~F}, 4 \mathrm{M}, \\
45.4 \pm 7.7) \\
16 \mathrm{HC}(11 \mathrm{~F}, \\
5 \mathrm{M}, 35.6 \\
\pm 7.6)\end{array}$ & Thermal & $\begin{array}{l}\text { Cerebellum, } \\
\text { midbrain } \\
\text { (including the } \\
\text { PAG), Rt } \\
\text { thalamus, Rt } \\
\text { insula, } \\
\text { lentiform } \\
\text { nucleus, Left } \\
\text { and Rt ACC, } \\
\text { Posterior } \\
\text { cingulate } \\
\text { cortex, Left } \\
\text { pre-motor } \\
\text { cortex }\end{array}$ \\
\hline $\begin{array}{l}\text { Giesecke } \\
\text { et al. ( } 54) \text {, } \\
\text { fMRI }\end{array}$ & $\begin{array}{l}\text { to identify } \\
\text { brain changes } \\
\text { in idiopathic } \\
\text { low back pain } \\
\text { and } \\
\text { fibromyalgia }\end{array}$ & $\begin{array}{l}\text { cLBP }>12 \\
\text { weeks } \\
\text { individuals } \\
\text { without } \\
\text { evidence of } \\
\text { any anatomic } \\
\text { abnormalitie } \\
\text { s on MRI or } \\
\text { plain } \\
\text { radiographs } \\
\text { that could } \\
\text { explain these } \\
\text { symptoms }\end{array}$ & $\begin{array}{l}\text { Guidelines and } \\
\text { exclusion } \\
\text { criteria } \\
\text { recommended } \\
\text { by Deyo et al. } \\
(55) \text { and } \\
\text { systemic } \\
\text { diseases }\end{array}$ & $\begin{array}{l}11 \mathrm{cLBP} \\
(8 \mathrm{~F}, 3 \mathrm{M}, 44 \pm \\
13) \\
11 \mathrm{HC} \\
(4 \mathrm{~F}, 7 \mathrm{M}, 41 \\
\pm 7)\end{array}$ & Pressure & $\begin{array}{l}\text { Contra-lateral } \\
\text { primary } \\
\text { somatosensory } \\
\text { cortex, } \\
\text { Contra-lateral } \\
\text { and ipsi-lateral } \\
\text { somatosensory } \\
\text { cortex, } \\
\text { Inferior } \\
\text { parietal } \\
\text { cortex, Insula, } \\
\text { ACC, } \\
\text { Cerebellum }\end{array}$ \\
\hline $\begin{array}{l}\text { Baliki MN et } \\
\text { al. (11), } \\
\text { fMRI }\end{array}$ & $\begin{array}{l}\text { Effect of brain } \\
\text { morphological } \\
\text { changes in }\end{array}$ & $\begin{array}{l}\text { Not } \\
\text { mentioned }\end{array}$ & Not mentioned & $\begin{array}{l}24 \mathrm{cLBP} \\
(18 \mathrm{~F}, 6 \mathrm{M}, \mathrm{Gr} 1 \\
49.2 \pm 17.2 \\
\text { and Gr2 } 50 \pm \\
12)\end{array}$ & Thermal & $\begin{array}{l}\text { Lt cerebellum, } \\
\text { Rt anterior } \\
\text { and mid } \\
\text { insula,Lt mid }\end{array}$ \\
\hline
\end{tabular}


medRxiv preprint doi: https://doi.org/10.1101/2021.08.26.21262683; this version posted August 28, 2021. The copyright holder for this preprint (which was not certified by peer review) is the author/funder, who has granted medRxiv a license to display the preprint in perpetuity.

All rights reserved. No reuse allowed without permission.

Brain Activation in Chronic Nonspecific Low Back Pain : A Systematic review and ALE Meta-analysis

\begin{tabular}{|c|c|c|c|c|c|c|}
\hline & $\begin{array}{l}\text { chronic } \\
\text { spontaneous } \\
\text { low back pain }\end{array}$ & & & $\begin{array}{l}11 \mathrm{HC} \\
(6 \mathrm{~F}, 5 \mathrm{M}, 48.7 \pm \\
11.2)\end{array}$ & & $\begin{array}{l}\text { insula, Rt } \\
\text { Precuneus, Rt } \\
\text { inferior and } \\
\text { posterior } \\
\text { parietal , R } \\
\text { mid frontal } \\
\text { DLPFC, mid } \\
\text { ACC/SMA }\end{array}$ \\
\hline $\begin{array}{l}\text { Lloyd } \\
\text { et al. (56), } \\
\text { fMRI }\end{array}$ & $\begin{array}{l}\text { To identify } \\
\text { brain changes } \\
\text { in cLBP } \\
\text { patients with } 4 \\
\text { or } 5 \text { positive } \\
\text { Waddell signs } \\
\text { (WS-H) and } \\
\text { those showing } \\
1 \text { or none } \\
\text { (WS-L) }\end{array}$ & $\begin{array}{l}\text { Clinically } \\
\text { diagnosed, } \\
\text { Pain > } 6 \\
\text { months; No } \\
\text { significant } \\
\text { radiological } \\
\text { involvement } \\
\text { in magnetic } \\
\text { resonance } \\
\text { imaging } \\
\text { (MRI) }\end{array}$ & $\begin{array}{l}\text { Major } \\
\text { neurological or } \\
\text { psychiatric } \\
\text { disease, head } \\
\text { trauma, current } \\
\text { drug or alcohol } \\
\text { abuse or } \\
\text { evidence of } \\
\text { cognitive } \\
\text { decline }\end{array}$ & $\begin{array}{l}30 \mathrm{cLBP} \\
(14 \mathrm{~F}, 16 \mathrm{M}, 45 \\
\pm 12.2) \\
17 \mathrm{HC} \\
(9 \mathrm{~F}, 8 \mathrm{M}, 31 \pm \\
8.1)\end{array}$ & Tactile & $\begin{array}{l}\text { Ventrolateral } \\
\text { and } \\
\text { dorsolateral } \\
\text { prefrontal } \\
\text { cortex, } \\
\text { Inferior } \\
\text { parietal lobe, } \\
\text { Insula and } \\
\text { Putamen, } \\
\text { Sup-med } \\
\text { frontal gyrus, } \\
\text { Primary and } \\
\text { Secondary } \\
\text { somatosensor } \\
\text { y cortex, } \\
\text { Anterior } \\
\text { cingulate } \\
\text { gyrus }\end{array}$ \\
\hline $\begin{array}{l}\text { Kobayashi et } \\
\text { al. (57), } \\
\text { fMRI }\end{array}$ & $\begin{array}{l}\text { To } \\
\text { characterize } \\
\text { the cerebral } \\
\text { substrates of } \\
\text { LBP, and to } \\
\text { explore a } \\
\text { possible } \\
\text { pathologic } \\
\text { pattern of ce- } \\
\text { rebral } \\
\text { activation in } \\
\text { chronic LBP } \\
\text { patients. }\end{array}$ & $\begin{array}{l}\text { Clinically } \\
\text { and } \\
\text { radiological } \\
\text { (MRI) } \\
\text { diagnosis }\end{array}$ & $\begin{array}{l}\text { Histories of } \\
\text { cerebrovascula } \\
\text { r disease, and } \\
\text { were free from } \\
\text { any } \\
\text { medication } \\
\text { within } 24 \\
\text { hours of the } \\
\text { study. }\end{array}$ & $\begin{array}{l}8 \mathrm{cLBP}(3 \mathrm{~F}, \\
5 \mathrm{M}) \\
8 \mathrm{HC}(8 \mathrm{M})\end{array}$ & Pressure & $\begin{array}{l}\text { Posterior } \\
\text { cingulate } \\
\text { cortex, } \\
\text { Rt.primary, } \\
\text { pre-motor } \\
\text { and } \\
\text { supplementar } \\
\text { y motor area, } \\
\text { Ri insula, Lt. } \\
\text { premotor } \\
\text { area, Rt. } \\
\text { prefrontal } \\
\text { cortex, Rt. } \\
\text { thalamus }\end{array}$ \\
\hline $\begin{array}{l}\text { Matsuo et al. } \\
\text { (58), fMRI }\end{array}$ & $\begin{array}{l}\text { Differences in } \\
\text { cerebral } \\
\text { reactivity to a } \\
\text { simulated low } \\
\text { back pain } \\
\text { stimulus }\end{array}$ & $\begin{array}{l}\text { cLBP was } \\
\text { defined as } \\
\text { low back } \\
\text { pain lasting } \\
\text { longer than } 3 \\
\text { months with }\end{array}$ & $\begin{array}{l}\text { No history of } \\
\text { cerebrovascular } \\
\text { disease, and } \\
\text { were free from } \\
\text { any } \\
\text { medications } \\
\text { within } 24 \mathrm{~h} \text {, } \\
\text { structural }\end{array}$ & $\begin{array}{l}11 \\
\text { cLBP(2F,9M, } \\
48 \pm 14.0) \\
13 \mathrm{HC}(0 \mathrm{~F}, 13 \\
\mathrm{M}, 34 \pm 13.9)\end{array}$ & Pressure & $\begin{array}{l}\mathrm{Lt} \text { and } \mathrm{Rt} \\
\text { superior } \\
\text { parietal } \\
\text { cortex, Lt } \\
\text { premotor area, } \\
\mathrm{Lt} \text { anterior } \\
\text { cingulate } \\
\text { cortex, Lt }\end{array}$ \\
\hline
\end{tabular}


medRxiv preprint doi: https://doi.org/10.1101/2021.08.26.21262683; this version posted August 28, 2021. The copyright holder for this preprint (which was not certified by peer review) is the author/funder, who has granted medRxiv a license to display the preprint in perpetuity.

All rights reserved. No reuse allowed without permission.

Brain Activation in Chronic Nonspecific Low Back Pain : A Systematic review and ALE Meta-analysis

\begin{tabular}{|c|c|c|c|}
\hline $\begin{array}{l}\text { between cLBP } \\
\text { patients and } \\
\text { healthy } \\
\text { controls by } \\
\text { functional } \\
\text { magnetic } \\
\text { reso- nance } \\
\text { imaging } \\
\text { (fMRI), and } \\
\text { their } \\
\text { behavioral } \\
\text { correlates } \\
\text { from a } \\
\text { psychophysica } \\
1 \\
\text { questionnaire. }\end{array}$ & $\begin{array}{l}\text { an NRS-i } \\
\text { score } \\
\text { (11point) of } \\
3 \text { or more, } \\
\text { McGill Pain } \\
\text { Questionnair } \\
\text { e Short Form } \\
\text { (MPQ) }\end{array}$ & $\begin{array}{l}\text { abnormalities } \\
\text { in the lumbar } \\
\text { spine on MRI } \\
\text { and any other } \\
\text { specific } \\
\text { neurologic } \\
\text { symptoms }\end{array}$ & DLPFC \\
\hline
\end{tabular}

ACC: Anterior cingulate cortex, cLBP : Chronic non-specific low back pain, DLPFC: Dorsolateral Prefrontal cortex, F: Female, HC : Healthy control, IASP : International association for the study of pain, Lt : Left M : Male, mPFC: Medial prefrontal cortex, PAG : Periaqueductal grey, Rt : Right, SEM : Standard error of mean, SMA: Supplementary motor area Age is given in mean \pm SD if not specified otherwise

Table 2a : Result of risk of bias assessment by Joanna Briggs Institute critical appraisal check list of the included studies in 'without stimulation' group

\begin{tabular}{|c|c|c|c|c|c|c|c|c|}
\hline Author, date & $\begin{array}{l}\text { Baliki et } \\
\text { al.(11) }\end{array}$ & $\begin{array}{l}\text { Tagliazucchi } \\
\text { et al. (47) }\end{array}$ & $\begin{array}{l}\text { Tagliazucchi } \\
\text { et al. (48) }\end{array}$ & $\begin{array}{l}\text { Baliki et } \\
\text { al.(49) }\end{array}$ & $\begin{array}{l}\text { Hashmi } \\
\text { et al (33) }\end{array}$ & $\begin{array}{l}\text { Kong et } \\
\text { al. (51) }\end{array}$ & $\begin{array}{l}\text { Baliki et } \\
\text { al. (14) }\end{array}$ & $\begin{array}{l}\text { Tu et } \\
\text { al.(34) }\end{array}$ \\
\hline $\begin{array}{l}\text { Were the criteria for } \\
\text { inclusion in the sample } \\
\text { clearly defined? }\end{array}$ & Unclear & Unclear & Unclear & Yes & Yes & Yes & Yes & Yes \\
\hline $\begin{array}{l}\text { Were the study subjects } \\
\text { and the setting described } \\
\text { in detail? }\end{array}$ & Yes & Yes & Yes & Unclear & Yes & Yes & Yes & Yes \\
\hline $\begin{array}{l}\text { Was the exposure } \\
\text { measured in a valid and } \\
\text { reliable way? }\end{array}$ & Yes & Yes & Yes & Yes & Yes & Yes & Yes & Yes \\
\hline $\begin{array}{l}\text { Were objective, standard } \\
\text { criteria used for } \\
\text { measurement of the } \\
\text { condition? }\end{array}$ & No & No & No & No & Yes & Yes & Yes & Yes \\
\hline $\begin{array}{l}\text { Were confounding } \\
\text { factors identified? }\end{array}$ & Unclear & No & No & Yes & Yes & No & Yes & Unclear \\
\hline $\begin{array}{l}\text { Were strategies to deal } \\
\text { with confounding factors } \\
\text { stated? }\end{array}$ & Unclear & No & No & Yes & Yes & No & Yes & No \\
\hline Were the outcomes & Yes & Yes & Yes & Yes & Yes & Yes & Yes & Yes \\
\hline
\end{tabular}


medRxiv preprint doi: https://doi.org/10.1101/2021.08.26.21262683; this version posted August 28, 2021. The copyright holder for this preprint (which was not certified by peer review) is the author/funder, who has granted medRxiv a license to display the preprint in perpetuity.

All rights reserved. No reuse allowed without permission.

Brain Activation in Chronic Nonspecific Low Back Pain : A Systematic review and ALE Meta-analysis

\begin{tabular}{|c|c|c|c|c|c|c|c|c|}
\hline $\begin{array}{l}\text { measured in a valid and } \\
\text { reliable way? }\end{array}$ & & & & & & & & \\
\hline $\begin{array}{l}\text { Was appropriate } \\
\text { statistical analysis used? }\end{array}$ & Yes & Yes & Yes & Yes & Yes & Yes & Yes & Yes \\
\hline
\end{tabular}

Table 2b : Result of risk of bias assessment by Joanna Briggs Institute critical appraisal check list of the included studies in 'with stimulation' group

\begin{tabular}{|c|c|c|c|c|c|c|}
\hline Author, date & $\begin{array}{l}\text { Derbyshire } \\
\text { et al. }(53)\end{array}$ & $\begin{array}{l}\text { Giesecke } \\
\text { et al. (54) }\end{array}$ & $\begin{array}{l}\text { Baliki et } \\
\text { al. (11) }\end{array}$ & $\begin{array}{l}\text { Lloyd } \\
\text { et al.(56) }\end{array}$ & $\begin{array}{l}\text { Kobayashi } \\
\text { et al. (57) }\end{array}$ & $\begin{array}{l}\text { Matsuo } \\
\text { et al. }(58)\end{array}$ \\
\hline $\begin{array}{l}\text { Were the criteria for inclusion in the sample clearly } \\
\text { defined? }\end{array}$ & Yes & Yes & Unclear & Yes & Yes & Yes \\
\hline $\begin{array}{l}\text { Were the study subjects and the setting described in } \\
\text { detail? }\end{array}$ & Yes & Yes & Yes & Yes & Yes & Yes \\
\hline $\begin{array}{l}\text { Was the exposure measured in a valid and reliable } \\
\text { way? }\end{array}$ & Yes & Yes & Yes & Yes & Yes & Yes \\
\hline $\begin{array}{l}\text { Were objective, standard criteria used for } \\
\text { measurement of the condition? }\end{array}$ & Unclear & Yes & No & Yes & Yes & Yes \\
\hline Were confounding factors identified? & Yes & Yes & Unclear & Unclear & No & Unclear \\
\hline $\begin{array}{l}\text { Were strategies to deal with confounding factors } \\
\text { stated? }\end{array}$ & Unclear & Yes & Unclear & Unclear & No & No \\
\hline $\begin{array}{l}\text { Were the outcomes measured in a valid and reliable } \\
\text { way? }\end{array}$ & Yes & Yes & Yes & Yes & Yes & Yes \\
\hline Was appropriate statistical analysis used? & Yes & Yes & Yes & Yes & Yes & Yes \\
\hline
\end{tabular}

Table 3a. Results of ALE meta-analysis of resting fMRI studies 'without stimulation' group

\begin{tabular}{|c|c|c|c|c|c|c|c|}
\hline Cluster & $\mathbf{X}$ & $\mathbf{Y}$ & $\mathbf{Z}$ & $\begin{array}{l}\text { ALE } \\
\left(10^{-3}\right)\end{array}$ & $\begin{array}{l}\text { Z } \\
\text { Score }\end{array}$ & $\begin{array}{l}\text { Size } \\
\left(\mathbf{m m}^{3}\right)\end{array}$ & Label \\
\hline 1 & -4 & 40 & -12 & 16.66 & 4.62 & 624 & $\begin{array}{l}\text { Hemisphere: } 76.9 \% \text { Left Cerebrum, } \\
\text { 16.7\% Inter-Hemispheric, } 6.4 \% \text { Right } \\
\text { Cerebrum } \\
\text { Lobe: } 76.9 \% \text { Limbic, } 6.4 \% \text { Frontal } \\
\text { Gyrus: } 76.9 \% \text { Anterior Cingulate, } 6.4 \% \\
\text { Medial Frontal Gyrus } \\
\text { Tissue Type: } 71.8 \% \text { Gray Matter, } \\
\text { 28.2\% White Matter } \\
\text { Cell Type: } 28.2 \% \text { BA 32, 9\% BA } 24 \text {, } \\
\text { 5.1\% BA } 10 \\
\text { Contributing studies : Baliki et al. }\end{array}$ \\
\hline
\end{tabular}


medRxiv preprint doi: https://doi.org/10.1101/2021.08.26.21262683; this version posted August 28, 2021. The copyright holder for this preprint (which was not certified by peer review) is the author/funder, who has granted medRxiv a license to display the preprint in perpetuity.

All rights reserved. No reuse allowed without permission.

Brain Activation in Chronic Nonspecific Low Back Pain : A Systematic review and ALE Meta-analysis

\begin{tabular}{|c|c|c|c|c|c|c|c|}
\hline & & & & & & & (11), Hashmi et al. (33), Tu et al. (34) \\
\hline 2 & -42 & -20 & 56 & 15.00 & 4.30 & 464 & $\begin{array}{l}\text { Hemisphere: } 100 \% \text { Left Cerebrum } \\
\text { Lobe: } 72.4 \% \text { Parietal, } 27.6 \% \text { Frontal } \\
\text { Gyrus: } 62.1 \% \text { Postcentral Gyrus, } 37.9 \% \\
\text { Precentral Gyrus } \\
\text { Tissue Type: } 84.5 \% \text { Gray Matter, } \\
\text { 15.5\% White Matter } \\
\text { Cell Type : } 37.9 \% \text { BA 3, } 25.9 \% \text { BA } 4 \\
\text { Contributing studies : Tagliazucchi et } \\
\text { al. (47), Tagliazucchi et al. (48), Tu et } \\
\text { al. (34) }\end{array}$ \\
\hline 3 & -4 & 48 & 0 & 17.85 & 4.85 & 456 & $\begin{array}{l}\text { Hemisphere: } 96.5 \% \text { Left Cerebrum, } \\
\text { 3.5\% Inter-Hemispheric } \\
\text { Lobe: } 82.5 \% \text { Limbic, } 14 \% \text { Frontal } \\
\text { Gyrus: } 82.5 \% \text { Anterior Cingulate, } 14 \% \\
\text { Medial Frontal Gyrus } \\
\text { Tissue Type: } 82.5 \% \text { Gray Matter, } \\
\text { 17.5\% White Matter } \\
\text { Cell Type : } 56.1 \% \text { BA } 32,10.5 \% \text { BA } \\
10 \\
\text { Contributing studies : Hashmi et al. } \\
\text { (33), Tu et al. (34) }\end{array}$ \\
\hline 4 & -40 & -6 & -2 & 13.81 & 4.07 & 416 & $\begin{array}{l}\text { Hemisphere: } 100 \% \text { Left Cerebrum } \\
\text { Lobe: } 100 \% \text { Sub-lobar } \\
\text { Gyrus: } 75 \% \text { Insula, } 13.5 \% \text { Extra- } \\
\text { Nuclear, } 11.5 \% \text { Claustrum } \\
\text { Tissue Type: } 69.2 \% \text { White Matter, } \\
\text { 30.8\% Gray Matter } \\
\text { Cell Type : } 19.2 \% \text { Brodmann area } 13 \\
\text { Contributing studies : Tagliazucchi et } \\
\text { al. (48), Baliki et al. (49), Kong et al. } \\
\text { (51) }\end{array}$ \\
\hline 5 & -14 & 56 & 20 & 14.06 & 4.12 & 328 & $\begin{array}{l}\text { Hemisphere: } 100 \% \text { Left Cerebrum } \\
\text { Lobe: } 100 \% \text { Frontal Lobe } \\
\text { Gyrus: } 100 \% \text { Superior Frontal Gyrus } \\
\text { Tissue Type: } 90.2 \% \text { White Matter, } \\
9.8 \% \text { Gray Matter } \\
\text { Cell Type : } 9.8 \% \text { Brodmann area } 9 \\
\text { Contributing studies : Baliki et al. } \\
\text { (11), Tu et al. (34). }\end{array}$ \\
\hline
\end{tabular}


medRxiv preprint doi: https://doi.org/10.1101/2021.08.26.21262683; this version posted August 28, 2021. The copyright holder for this preprint (which was not certified by peer review) is the author/funder, who has granted medRxiv a license to display the preprint in perpetuity.

All rights reserved. No reuse allowed without permission.

Brain Activation in Chronic Nonspecific Low Back Pain : A Systematic review and ALE Meta-analysis

\begin{tabular}{|c|c|c|c|c|c|c|c|}
\hline 6 & -28 & 8 & 0 & 11.93 & 3.74 & 264 & $\begin{array}{l}\text { Hemisphere: } 100 \% \text { Left Cerebrum } \\
\text { Lobe: } 100 \% \text { Sub-lobar } \\
\text { Gyrus: } 57.6 \% \text { Lentiform Nucleus, } \\
\text { 42.4\% Extra-Nuclear } \\
\text { Tissue Type: } 57.6 \% \text { Gray Matter, } \\
\text { 42.4\% White Matter } \\
\text { Cell Type: } 57.6 \% \text { Putamen } \\
\text { Contributing studies: Hashmi et al. } \\
\text { (33), Tu et al. (34) }\end{array}$ \\
\hline 7 & -24 & -4 & -18 & 11.94 & 3.74 & 224 & $\begin{array}{l}\text { Hemisphere: } 100 \% \text { Left Cerebrum } \\
\text { Lobe: } 100 \% \text { Limbic Lobe } \\
\text { Gyrus: } 100 \% \text { Parahippocampal Gyrus } \\
\text { Tissue Type: } 67.9 \% \text { Gray Matter, } \\
32.1 \% \text { White Matter } \\
\text { Cell Type: } 67.9 \% \text { Amygdala } \\
\text { Contributing studies: Kong et al. (51), } \\
\text { Hashmi et al. (33) }\end{array}$ \\
\hline 8 & 50 & -12 & 52 & 12.68 & 3.88 & 216 & $\begin{array}{l}\text { Hemisphere: } 100 \% \text { Right Cerebrum } \\
\text { Lobe: } 70.4 \% \text { Parietal Lobe, } 29.6 \% \\
\text { Frontal Lobe } \\
\text { Gyrus: } 66.7 \% \text { Postcentral Gyrus, } 33.3 \% \\
\text { Precentral Gyrus } \\
\text { Tissue Type: } 77.8 \% \text { Gray Matter, } \\
\text { 22.2\% White Matter } \\
\text { Cell Type: } 55.6 \% \text { BA 3, 22.2\% BA } 4 \\
\text { Contributing studies: Tagliazucchi et } \\
\text { al. (47), Tagliazucchi et al. (48) }\end{array}$ \\
\hline
\end{tabular}

Co-ordinates of the clusters (X,Y,Z) are provided in MNI (Montreal Neurological Institute) co-ordinate System of the human brain, Cluster forming values : threshold of ALE map the $\mathrm{P}$ $<0.05$ corrected for cluster-level family-wise error (FWE) and $\mathrm{P}<0.001$ voxel-level forming threshold (uncorrected), threshold for minimum cluster size is $>200 \mathrm{~mm}^{3}$

Table 3b. Results of ALE meta-analysis of resting fMRI studies 'with stimulation' group

$$
\begin{array}{l|l|l|l|l|l|l|l|}
\text { Cluster } & \mathbf{X} & \mathbf{Y} & \mathbf{Z} & \begin{array}{l}
\text { ALE } \\
\left(\mathbf{1 0}^{-3}\right)
\end{array} & \begin{array}{l}
\mathrm{Z} \\
\text { Score }
\end{array} & \begin{array}{l}
\text { Size } \\
\left(\mathrm{mm}^{3}\right)
\end{array} & \text { Label } \\
\hline
\end{array}
$$


medRxiv preprint doi: https://doi.org/10.1101/2021.08.26.21262683; this version posted August 28, 2021. The copyright holder for this preprint (which was not certified by peer review) is the author/funder, who has granted medRxiv a license to display the preprint in perpetuity.

All rights reserved. No reuse allowed without permission.

Brain Activation in Chronic Nonspecific Low Back Pain : A Systematic review and ALE Meta-analysis

\begin{tabular}{|c|c|c|c|c|c|c|c|}
\hline 1 & 50 & 4 & 10 & 18.92 & 5.61 & 1560 & $\begin{array}{l}\text { Hemisphere: } 100 \% \text { Right Cerebrum } \\
\text { Lobe: } 53.3 \% \text { Frontal Lobe, } 46.7 \% \text { Sub- } \\
\text { lobar } \\
\text { Gyrus: } 45.6 \% \text { Insula, } 40 \% \text { Precentral } \\
\text { Gyrus, } 13.3 \% \text { Sub-Gyral, 1\% Extra- } \\
\text { Nuclear } \\
\text { Tissue Type: } 78.5 \% \text { White Matter, } 21.5 \% \\
\text { Gray Matter } \\
\text { Cell Type: } 11.8 \% \text { BA 44, 9.7\% BA } 13 \\
\text { Contributing studies: Derbyshire et al. } \\
\text { (53), Baliki et al. (11), Lloyd et al. (56), } \\
\text { Kobayashi et al. (57) }\end{array}$ \\
\hline 2 & 62 & -20 & 18 & 15.34 & 4.87 & 576 & $\begin{array}{l}\text { Hemisphere: } 100 \% \text { Right Cerebrum } \\
\text { Lobe: } 100 \% \text { Parietal Lobe } \\
\text { Gyrus: } 100 \% \text { Postcentral Gyrus } \\
\text { Tissue Type: } 88.9 \% \text { White Matter, } 11.1 \% \\
\text { Gray Matter } \\
\text { Cell Type: } 9.7 \% \text { BA } 40 \\
\text { Contributing studies: Giesecke et al. } \\
\text { (54), Loyd et al. (56) }\end{array}$ \\
\hline 3 & 4 & 20 & 42 & 11.70 & 4.15 & 480 & $\begin{array}{l}\text { Hemisphere: } 61.7 \% \text { Right Cerebrum, } \\
23.3 \% \text { Inter-Hemispheric, 15\% Left } \\
\text { Cerebrum } \\
\text { Lobe: } 50 \% \text { Frontal Lobe, } 26.7 \% \text { Limbic } \\
\text { Lobe } \\
\text { Gyrus: } 26.7 \% \text { Cingulate Gyrus, } 26.7 \% \\
\text { Medial Frontal Gyrus, 23.3\% Superior } \\
\text { Frontal Gyrus } \\
\text { Tissue Type: } 66.7 \text { White Matter, 33.3\% } \\
\text { Gray Matter } \\
\text { Cell Type: } 15 \% \text { BA 8, 10\% BA 6, 8.3\% } \\
\text { BA 32 } \\
\text { Contributing studies: Giesecke et al. } \\
\text { (54), Lloyd et al. } 2008 \text { (56), Kobayashi et } \\
\text { al. (57) }\end{array}$ \\
\hline
\end{tabular}


medRxiv preprint doi: https://doi.org/10.1101/2021.08.26.21262683; this version posted August 28, 2021. The copyright holder for this preprint (which was not certified by peer review) is the author/funder, who has granted medRxiv a license to display the preprint in perpetuity.

All rights reserved. No reuse allowed without permission.

Brain Activation in Chronic Nonspecific Low Back Pain : A Systematic review and ALE Meta-analysis 
medRxiv preprint doi: https://doi.org/10.1101/2021.08.26.21262683; this version posted August 28, 2021. The copyright holder for this preprint (which was not certified by peer review) is the author/funder, who has granted medRxiv a license to display the preprint in perpetuity.

All rights reserved. No reuse allowed without permission.

Brain Activation in Chronic Nonspecific Low Back Pain : A Systematic review and ALE Meta-analysis

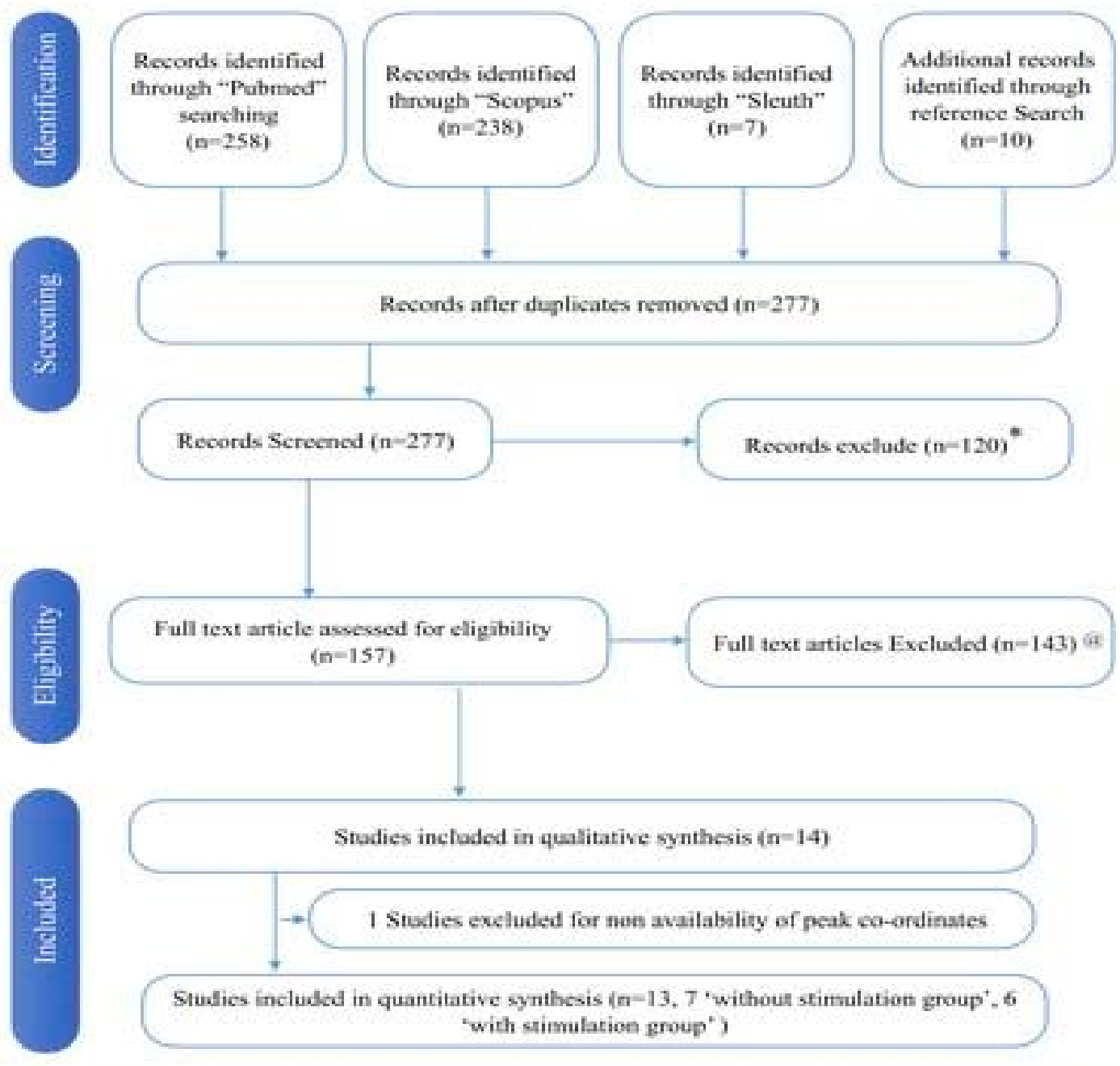

- No brain imaging, neviews, animal studies, case reports, no full text, studies not written in English language, studics that are not peer reviewed

(a) No whole brain analyxis, structural imaging, no standard stereotactic space coondinates (Talairach or Montreal Neurological Institute)

Figure : 1 : PRISMA FLOW Diagram showing the sequence of literature search and process of inclusion and exclusion of articles according to PRISMA statement (http://www.equatornetwork.org/reporting-guidelines/prisma/) 
Brain Activation in Chronic Nonspecific Low Back Pain : A Systematic review and ALE Meta-analysis

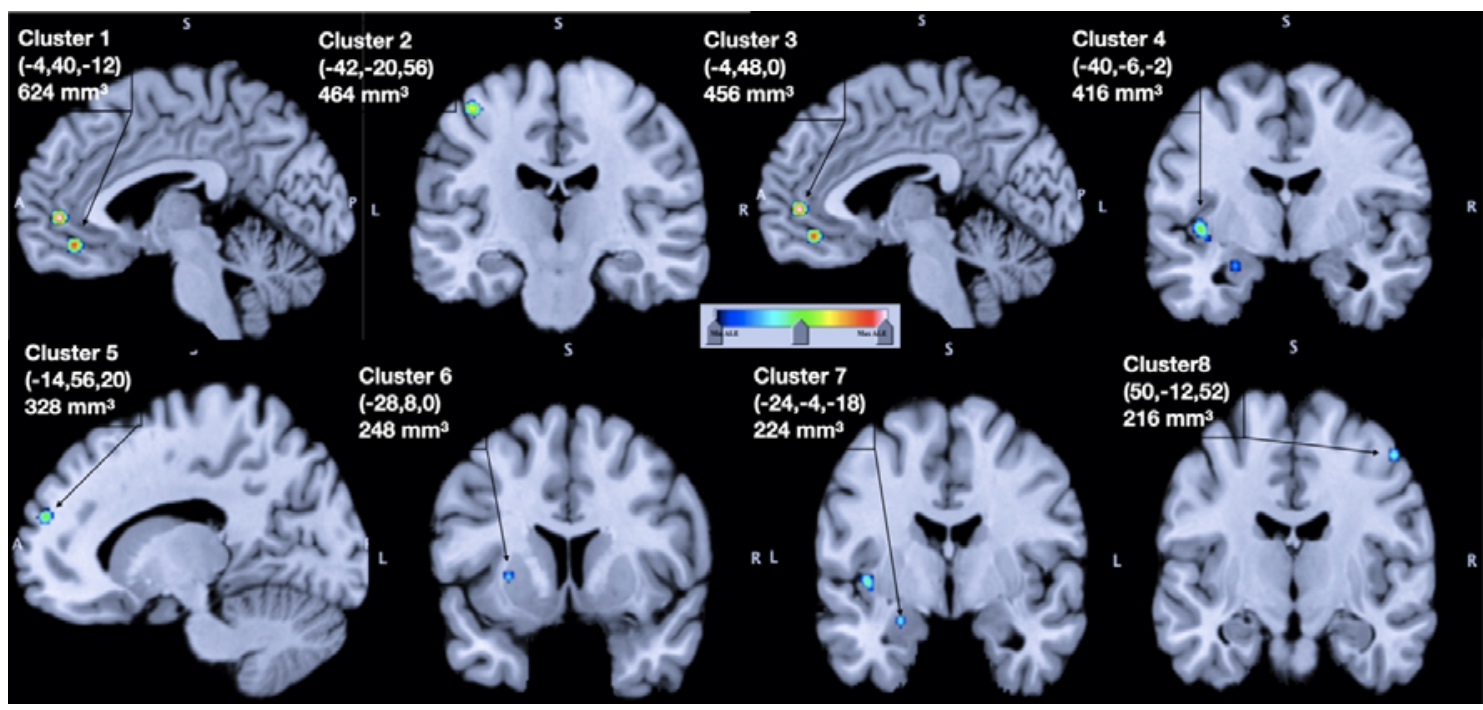

Figure : 2a : Result of ALE meta-analysis for the studies in 'without stimulation' group. The result is overlaid on the brain anatomical template provided on GingerALE Website (Colin27_T1_seg_MNI.nii, http://brainmap.org/ale). Red : Strong association, Green :

Moderate association, Blue : Weaker association. Co-ordinates of the clusters $(\mathrm{X}, \mathrm{Y}, \mathrm{Z})$ are provided in MNI (Montreal Neurological Institute) co-ordinate System of the human brain, $\mathrm{mm}^{3}$ : area of the cluster in cubic millimetre. Cluster forming values : threshold of ALE map the $\mathrm{P}<0.05$ corrected for cluster-level family-wise error (FWE) and $\mathrm{P}<0.001$ voxel-level forming threshold (uncorrected), threshold for minimum cluster size is $>200 \mathrm{~mm}^{3}$

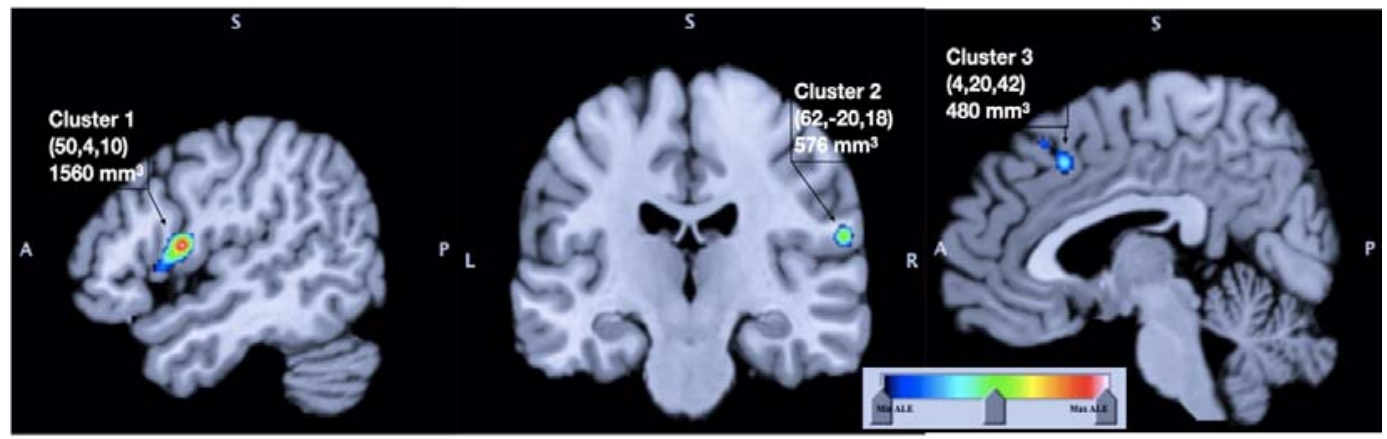


medRxiv preprint doi: https://doi.org/10.1101/2021.08.26.21262683; this version posted August 28, 2021. The copyright holder for this preprint (which was not certified by peer review) is the author/funder, who has granted medRxiv a license to display the preprint in perpetuity.

All rights reserved. No reuse allowed without permission.

Brain Activation in Chronic Nonspecific Low Back Pain : A Systematic review and ALE Meta-analysis

Figure : 2b : Result of ALE meta-analysis for the studies in 'with stimulation' group. The result is overlaid on the brain anatomical template provided on GingerALE Website

(Colin27_T1_seg_MNI.nii, http://brainmap.org/ale). Red : Strong association, Green :

Moderate association, Blue : Weaker association. Co-ordinates of the clusters $(\mathrm{X}, \mathrm{Y}, \mathrm{Z})$ are provided in MNI (Montreal Neurological Institute) co-ordinate System of the human brain, $\mathrm{mm}^{3}$ : area of the cluster in cubic millimetre. Cluster forming values : threshold of ALE map the $\mathrm{P}<0.05$ corrected for cluster-level family-wise error (FWE) and $\mathrm{P}<0.001$ voxel-level forming threshold (uncorrected), threshold for minimum cluster size is $>200 \mathrm{~mm}^{3}$ 